\title{
Critical points for the control of Tuberculosis on Primary Health Care
}

\author{
Pontos de estrangulamento sobre o controle da tuberculose na atenção primária \\ Puntos de estrangulamiento sobre el control de la tuberculosis en la atención primaria
}

\section{Patrícia Geórgia Oliveira Diniz Pinheiro', Lenilde Duarte de Sá', Pedro Fredemir Palha", Rita de Cássia Cordeiro de Oliveira', Jordana de Almeida Nogueira', Tereza Cristina Scatena Villa"}

' Universidade Federal da Paraíba, Postgraduate Program in Nursing. João Pessoa-PB, Brasil.

"Universidade de São Paulo, Nursing School of Ribeirão Preto, Postgraduate Program in Nursing. Ribeirão Preto-SP, Brasil.

\section{How to cite this article:}

Pinheiro PGOD, Sá LD, Palha PF, Oliveira RCC, Nogueira JA, Villa TCS. Critical points for the control of Tuberculosis on Primary Health Care. Rev Bras Enferm [Internet]. 2017;70(6):1227-34. DOI: http://dx.doi.org/10.1590/0034-7167-2016-0467

\section{ABSTRACT}

Objective: To analyze the discourses of professionals that work on the reference service about the critical points that affects the essential attributes of the Primary Health Care (PHC) related to the control of tuberculosis in the city of João Pessoa. Method: The empirical material collected from August to October in 2014, through the interview technique was analyzed through the methodologicaltheoretical framework of French Discourse Analysis. Results: The discourses demonstrated the critical points on the control of the disease on PHC as being the lack of bond and welcoming from the professionals in relation to patients with tuberculosis. It was realized that the professionals have prejudice about the disease, that they have difficulties on the access to conducting exams, appointments and treatments, as well as there are fails on the reference and counter-referencing system. Final Considerations: Managers should be aware about the results that were found, so that facing actions can be planned and executed in order to minimize the existent of critical points. Descriptors: Tuberculosis; Primary Health Care; Nursing; Healthcare Policy; Healthcare Management.

\section{RESUMO}

Objetivo: Analisar os discursos de profissionais atuantes no serviço de referência sobre pontos de estrangulamento que afetam os atributos essenciais da atenção primária à saúde (APS) relacionados ao controle da tuberculose no município de João Pessoa. Método: $\mathrm{O}$ material empírico coletado nos meses de agosto a outubro de 2014 mediante técnica de entrevista foi analisado por meio do dispositivo teórico-analítico de Análise de Discurso, na linha francesa. Resultados: Os discursos explicitaram os pontos de estrangulamento no controle da doença na APS como sendo a ausência de vínculo e de acolhimento dos profissionais em relação ao doente de tuberculose. Percebeu-se preconceito por parte dos profissionais, dificuldades de acesso à realização de exames, consultas e tratamento bem como falhas no sistema de referência e contrarreferência. Considerações finais: Convém tornar os gestores cientes dos resultados encontrados, para que ações de enfrentamento sejam planejadas e executadas a fim de minimizar os pontos de estrangulamento existentes.

Descritores: Tuberculose; Atenção Primária à Saúde; Enfermagem; Política de Saúde; Gestão em Saúde.

\section{RESUMEN}

Objetivo: Analizar los discursos de profesionales actuantes en el servicio de referencia sobre los puntos de estrangulamiento que afectan los atributos esenciales de la atención primaria de la salud (APS) relacionados con el control de la tuberculosis en el municipio de João Pessoa. Método: El material empírico se recolectó entre los meses de agosto y octubre de 2014 mediante técnica de entrevista y se analizó bajo el dispositivo teórico-analítico de Análisis del Discurso, en la línea francesa. Resultados: Los discursos categorizaron los puntos de estrangulamiento en el control de la enfermedad en la APS, en ausencia de vínculo y de acogida de los profesionales con relación al enfermo de tuberculosis. Se evidenciaron prejuicios de parte de los profesionales, dificultad de acceso a la realización de exámenes, consultas y tratamientos así como fallas en el sistema de referencia y contrarreferencia. Consideraciones finales: Es conveniente que los gestores tomen conciencia de los resultados encontrados, para poder planificar y ejecutar acciones con el fin de minimizar los puntos de estrangulamiento existentes.

Descriptores: Tuberculosis; Atención Primaria de la Salud; Enfermería; Política de Salud; Gestión en Salud. 


\section{INTRODUCTION}

This study integrates a multicentric research - Research about neglected diseases, Tuberculosis: analysis of the critical points for Primary Health Care for the control of the disease on the municipalities from south, southwest and northwest regions from Brazil (MCTI/CNPq/MS-SCTIE - Decit nº 40/2012).

The Ministry of Health (MS), considering the permanence of tuberculosis and its severity in Brazil, determined that the disease had to be insert in one of the priority lines for the national policy of Brazilian Primary Care (National Primary Care Policy - PNAB) ${ }^{(1)}$ linked to the services from Primary Health Care (PHC), precisely, the Family Healthcare Strategy Units (FHS) and Primary Care Units (PCU).

The PHC works as the most recommended gateway of the user on the health system. It is featured by the following essential attributes: The provision of the services of first contact; the taking of a long-term responsibility for the patient with the permanency of the relation team-patient throughout life; the assurance of integrality of actions and services, or integral care, thinking about the physical, mental and social points of the health, inside of the limits of health team's actions; and the coordination of many actions and services which are indispensable to solve some needs that are unusual but more complex than the others ${ }^{(2)}$.

Among the various actions which are part of the PHC Services' competence, the activities linked to TB control gains prominence. These activities go through the Pursuit of Respiratory Symptoms (PRS) on the subscribed community; performance of tests for diagnosis (Sputum smear microscopy, tuberculin skin test, radiography); assurance of efficient communication flow with the laboratories until the treatment can follow the right clinical management and control of the communicators ${ }^{(3)}$.

The Brazilian health records database states that in 2013, 71,123 new cases of TB have been notified and 2.3 thousand deaths from this disease, putting the country again on the $16^{\circ}$ ranking position on the number of cases among the 22 countries that are responsible for $82 \%$ of all the cases of this disease in the whole world. João Pessoa, the city that was chosen to be the place of study for the development of this study presents the cure's percentage of the pulmonary bacilliferous on the period between 2010 to $2013^{(5)}$ as $67.8 \%, 69.8 \%, 64.2 \%$ and $54.3 \%$, respectively; and of abandonment of the treatment as $17.1 \%, 20.1 \%, 19.3 \%$ and $17.2 \%$. It indicates the decreasing tendency of cure and crescent rate for the abandonment of the treatment, which keep away from the goals set by the World Health Organization (WHO), which is to reach $85 \%$ of cure of the positive bacilliferous and reduce to $5 \%$ the percentage of abandonment of the treatment ${ }^{(4)}$. This situation points the difficulties that the municipality has to face on the driving of the actions for the control of the TB.

Beyond these percentages, the numbers of the statistic and descriptive report of the Epidemiology Department of the Clementino Fraga Hospital (CHCF) 2011-2014 points that there is a contradiction when it comes about the performance of $\mathrm{PHC}$ as a gateway to the execution of actions and services on the TB control, since this document revealed that this service was responsible for the diagnosis and the treatment of 807 (71.4\%) and 842
(74.9\%) of the 1.336 and 1.405 cases of TB that are recorded on SINAN ${ }^{(6)}$ in 2012 and 2013, respectively. It indicates the slow incorporation of the disease control's actions of the FHSU/PCU.

It should be informed that João Pessoa is the capital of the state of Paraíba, which is considered for the Ministry of Health as the priority on the actions of tuberculosis control, and since 2007, it started the exchange's process of the TB control's actions for PHC services, which before were centralized on $\mathrm{CHCF}$, the Reference Unit for the state ${ }^{(7)}$. However, the statistics above points out disabilities on the process of decentralization, since it shows that the city does not have TB control's actions, according to the attributes of $\mathrm{PHC}$ on the family health team's assistance to the people with TB.

In this perspective, facing the impact provided for the morbidity and mortality related to TB, it can be concluded that the development of actions linked to the essential attributes from PHC: The provision of the first contact services; the taking of a long-term responsibility for the patient with the permanency of the relation team-patient throughout life; the assurance of integrality of actions and services ${ }^{(3)}$, or integrality of care, thinking about the physical, mental and social points of the health, inside of the limits of health team's actions, is imperative for disease control, as well as the recognition of the critical points which affects the performance of this attributes. About critical points, it can be understood as the designation of the component that limits the performance, the capacity or the speed of a whole system ${ }^{(8)}$.

Based on a literature review in national and international journals, numerous researches conducted on TB control in the state of Paraíba, the barriers and critical points that affect the essential attributes of PHC, which limit the speed and flow of success to be made possible for the effective control of the disease through PHC services are still unknown.

In this sense, the contradictions about the statistic data showed on the report from CHFC related to the TB diagnosis and treatment, considering the slow incorporation of the attributes from $\mathrm{PHC}$ in the municipality and the organizational aspects that involves the TB control's actions of this reference Unit - the CHCF to the Services from $\mathrm{PHC}$, it is necessary to investigate the critical points that are related to the TB control in João Pessoa, through the discourses from the professionals working for $\mathrm{CHCF}$.

Thus, the research question is: What are the representations from the discourses of professionals working on the reference service about the critical points affecting the PHC essential attributes related to the TB control in the city of João Pessoa?

Therefore, this study aimed to analyze the discourses from the professionals working on the reference service about the critical points, affecting the $\mathrm{PHC}$ essential attributes related to TB control in the city of João Pessoa.

\section{METHOD}

\section{Ethical aspects}

The study was approved by the Research Ethics Committee of the Health Science Centre from the Federal University of Paraíba (Universidade Federal da Paraíba), according to the resolution 466/12 from the National Health Council, which states the development of researches involving human beings. 
Methodological-Theoretical framework and type of study

This is a descriptive and exploratory study with qualitative approach. The study type allowed us to describe and explore the senses and meanings that healthcare professionals points out about the critical points affecting the PHC essential attributes to TB control in the city of João Pessoa.

To justify the analysis and discussion about the data, we chose the French discourse analysis from Michel Pêcheux' approach as methodological-theoretical framework ${ }^{(9)}$.

\section{Methodological Procedures}

\section{Study setting}

The study was conducted in the city of João Pessoa, State of Paraíba, Brazil. The participants were enrolled in the ambulatory of the Clementino Fraga Hospital (CHCF). It integrates the hospital network of the Paraiba state as a Reference Unit for the TB diagnosis and treatment, representing as one of the gateways for TB control, which justifies the option for this study setting.

\section{Data sources}

A total of 12 healthcare professionals participated in the study, four nurses and 8 physicians. They work for $\mathrm{CHCF}$, and they were selected because they fulfill the following inclusion criteria: perform actions on TB control and treatment for patients in the CHFC outpatient service; worked in the hospital during data collection and were interested in participating in the study. The healthcare professionals that worked in the CHCF hospitalization department were excluded, since they do not perform outpatient service actions for TB control, thus, it is important to participate in the control and treatment for the disease from the diagnosis to discharge.

\section{Data collection and organization}

The data collection was performed from August to October 2014 through interview technique, with the contribution of a semi structured script. The interviews were performed individually, using a MP4 audio device in places chosen by the participants in the hospital, after the clarification about the ethical aspects by the reading, delivering and signing of the Consent Form. In order to keep the anonymity, participants were identified through the text with the letters NU (Nurse) and PH (Physician), followed with Arabic numerals representing the sequence of the interviews (NU1 to NU4 and PH1 to PH8).

\section{Data analysis and Steps of the analysis}

The empiric data were analyzed through the theoretical device from Discourse Analysis (DA) ${ }^{(9)}$. The DA reflects about how language is materialized in the ideology and how the ideology is expressed by language, working the relation between language-discourse-ideology, realizing that there is no discourse without the subject and there is no subject without the ideology: the individual is interpellated on the subject by the ideology, therefore, language makes sense $\mathrm{e}^{(10)}$. Thus, the accuracy of discourse analysis comes from the possibility to this analytic theoretical reference to reveal the worldview as well as the position of the subjects in relation to the study object.
The discourse analysis was set on the transition from the empirical material, as the transcribed interviews, to the discursive object by the following steps: 1) from the linguistic approach to the text (discourse); 2) from the discursive object to the discursive formation (DF); and 3) from the discursive process to the ideological formation ${ }^{(9,11)}$.

\section{RESULTS}

The attributes observed in the PHC are important to assure the results and quality of care. The operation of these attributes in its entirety is the determining factor to a quality care. There are evidences produced in Brazil, that the heterogeneous quality from $\mathrm{PHC}$ is related to the fact that the concepts and actions that are the basis for one or more attributes are not performed ${ }^{(12)}$.

Being aware about this knowledge, CHCF professionals' discourses were analyzed which were interpellated by the discourses from TB patients, highlighting textual marks capable to explicit, through the observation from the essential attributes - First Contact, Longitudinally, Integrality and Coordination of PHC -, critical points that compromises the success of this attributes on the control's actions of the disease. When these textual marks are grouped, it confirms a DF: Critical points that affects the essential attributes on the control of tuberculosis in João Pessoa/PB.

Critical points which affects the essential attributes from Primary Health Care on the control of tuberculosis in João Pessoa/PB.

\section{First Contact attribute}

When questioned about the preference from the patients to use the $\mathrm{CHCF}$ as the gateway to the diagnosis and treatment of TB, it was identified that the professional, on their discourses, said that, despite of the decentralization of the control's actions for the TB to $\mathrm{PHC}$, the users from the service preferred the CHCF instead of FHS unit, which indicates that the First Contact attribute fails because it shows the difficulties related to the access, appointments, exams and treatments on PHC as critical points, this way preventing the success of this attribute:

[...] there are many reasons that they (TB patients) explain during the appointment. Now one of the reasons we see more frequently is the lack of care when they go to the hospital: it doesn't have nurses, or it doesn't have doctors, and they postpone the treatment and get worse. [...] some of them (TB patients) also relate that they don't take the smear microscopy exam (on $\mathrm{PHC}$ ) and others get into the hospital with the reference to perform it here in the hospital. (NU2)

[...] what they (TB patients) say is that they have difficulties coming to the appointments and on the performance of exams. (PH2)

[...] the patients say that, when they get into the $B H U$, there is no one to see them, no doctors, no medication, that is what they tell us. (PH4) 


\section{Longitudinally attribute}

Longitudinally attribute, which is related to the establishment of the bond, reception and long-term responsibility fails its purpose as well, since the discourse of the professionals from $\mathrm{CHCF}$ points that the TB patients are going to private health services to search for care due to the lack of reception and bond with the PHC:

[...] they don't make (on PHC) the active search; then, if they don't identify the patients, they don't have any chances to create a bond [...]; in private health services (the $\mathrm{CHCF}$ ) they find the reception that they need. (NU1)

[...] There are many mistakes because if it was ok, we wouldn ' $t$ be facing this huge number of cases here on Clementino. The reception from the units fails in its service, here in the state capital city, we have the minimum number of people that get to receive the treatment for TB on the units. I believe that the problem is the reception. (NU3)

Patients also search for the CHCF services because of the lack of long-term responsibility, which is necessary to the formation of bonds between the professionals from $\mathrm{PHC}$ and the TB patients, since they send these TB patients from their cities to look for this private care center:

[...] Professionals (from PHC) are running away from tuberculosis. "It is that thing: there is a patient there, they (PHC professionals) say: "go to the Clementino, there they will give the treatment". (NU2)

[...] They (TB patients) are not examined on this FHS unit, and beyond all of that, there is one old practice, they (PHC healthcare professionals) send all of the patients with tuberculosis to the Clementino Fraga Hospital. (PH3)

It may be that the fact of the $\mathrm{PHC}$ professional send $\mathrm{TB}$ patients from their units to the CHCF is related to the prejudice that these people bring to their discursive memories. This comprehension was identified on the discourse of NP4:

[...] When the patient is coming, we signal to each other (healthcare professionals from $\mathrm{PHC}$ ) and say: "Look, people, the patient, you should wear a mask". Recently we received a patient that was starting the treatment for tuberculosis; she had been treated in another service. The nurse was providing care when the doctor said: "It is a tuberculosis patient"; and immediately ordered the patient to turn her face and put a mask because she would be infecting everyone, and it was not said in a polite way. The patient had already an impact to know that had tuberculosis, and you go and order her to "turn" [...] 'Turn to the other side because you are infecting everyone, you have tuberculosis'. For sure, it may put the patient away from the healthcare unit, from the hospital, even from the department where you are receiving the patient [...]. (NU4)

\section{Integrality Attribute}

It has been observed in the discourses of the CHCF professionals that they show the lack of organization of the PHC services to meet the needs of TB patients with regard to care, exams and medications, which is equivalent to the diagnosis and treatment of the disease. This means that TB patients in the city of João Pessoa do not have safety in PHC units:

[...] they (TB patients) are traumatized by the lack of care. In the matter of missing everything in FHS unit, they say: well, doctor, there is nothing there. (PH5)

[...] They complain a lot about it (from FHS unit): the delay in scheduling and the difficulty in performing the exams. They say it takes too long. [...] people here (in CHCF) have X-rays, a bacilloscopy; The patient comes and take the exam and solves their problem pretty much on the same day. (PH6)

[...] lack of professionals, mostly doctors at the BHU to do the following, I believe that's it. (PH7)

[...] as patients tell me, the main difficulty is patient safety (FHU) for further testing, continuity of treatment and continuity of medication delivery. (PH8)

\section{Coordination Attribute}

If TB patients are looking for or being referred to the $\mathrm{CHCF}$ from the $\mathrm{PHC}$, then, communication between the services should facilitate following these patients from $\mathrm{PHC}$, however, according to the discursive fragments presented for NU2, $\mathrm{PH} 5$ and $\mathrm{PH} 8$, this action is not taken:

[...] I think that each referred patient should be linked to Clementino and talk. If they know about the service, then it is not a big deal 'I'm going to refer this patient, please, receive this patient and give me a position about it', I think that if this communication happens, this feedback, the thing would work [...] we don't have a linked situation, Clementino and FHS unit, I think it would help a lot today on this dead-lock, that is on this extensive demand here on the hospital. (NU2)

[...] when the patient is already at the basic unit, a mismatch happens; for example, the exams that he does there in the basic unit doesn't come to us; [...] then, when it is in the end, to receive the discharge for tuberculosis, they come back to us, but they come back without exams, without report from the Unit. (PH5)

[...] the other point is that the communication could be done on a more technological way, but currently, it is done by letters. (PH8)

Another important aspect to be highlighted is that we can realize that on the middle of the discourse from the professional $\mathrm{PH} 2$, there is an overload and lack of work conditions for the professionals from PHC where they work directly with the activities linked to TB, according to the following discourse:

[...] we must consider our working conditions [...]. In the BHU, we know that it is poor; it is a unit that treats everything, Diabetes, hypertension, pregnant women, children, older people and infectious diseases. So, I think it an overload of work, despite of the number of cases (of TB) are very low, but I believe that on the unit, they just don't dedicate themselves more because of the lack of working conditions. I've been a doctor at the BHU, 
I've been a doctor at the FHS unit, and I saw, I felt it on my own, we had the will to work, we had the will to act, but many times, we didn't have the favorable conditions. ( $\mathrm{PH} 2)$

\section{DISCUSSION}

Through the discourse analysis approach, we observed the critical points affecting the PHC essential attributes in the professionals' discourses from the city of João Pessoa that are linked to the access to the medical appointments, tests and medications, welcoming and bonding, accountability of the professionals, attendance on the FHS unit, agility on the diagnosis, the TB patient's trust on the services from FHS unit and the communication between the services from $\mathrm{PHC}$ and $\mathrm{CHCF}$.

The first attribute identified in the analysis refers to the first contact, which claims the access and use of the services to each new problem or new episode of people looking for healthcare service ${ }^{(13)}$. The first contact can be defined as the gateway to the healthcare services. When the population and the team identify that service as the first resource to be sought when there is need or health problem ${ }^{(13)}$.

In other words, the term first contact in the TB control in $\mathrm{PHC}$ is related to the gateway or the access that TB patients have to the appointments with healthcare professionals, tests necessary to the diagnosis and medications for TB treatment.

According to the discursive excerpts presented, TB patients, from the city of João Pessoa, do not have access to the PHC services for TB control, thus, they look for $\mathrm{CHCF}$ to have the proper attention. Although, the fulfillment from $\mathrm{PHC}$ as a gateway service with the role to assure care for the most parts of the healthcare needs, requiring geographic, temporal and cultural access ${ }^{(14)}$.

In this sense, the fact that the patients are looking for the CHCF to obtain the diagnosis and treatment can be related to reasons that are directly linked to the lack of resolution of the PHC services: Regarding PHC resoluteness, it is known that it is associated to many factors such as: physical structure of the units, management and work process, the professionals' training and, in the most part, the access to the specialized services and tests ${ }^{(14)}$.

To promote better care to the TB patient, the National Plan for Tuberculosis Control ${ }^{(15)}$ for the period 2001 to 2005 was inserted as FHS work proposal, considering that the decentralization of the TB control's actions for the PHC' scope would enlarge the access of the patients to the healthcare services ${ }^{(16)}$. Therefore, we emphasize that the way that healthcare services are organized to favor TB control's actions is linked to the decentralization process.

However, it seems as if the exchange of the TB control's actions for the PHC, in the city of João Pessoa was not satisfactory, since the way of organization of the services, related to the attribute First Contact was not a determining factor for the assurance of the access to early diagnosis and treatment of the disease.

It was evident in the discourse of CHCF professionals' that there are critical points that affect the attribute longitudinally, since the TB patients of the city of João Pessoa look for the reference unit to obtain the TB diagnosis and treatment, because they are not welcomed or they do not have the bond with the FHS unit from their coverage area.
The presence of the attribute longitudinally, linked to welcoming and bonding tends to produce more accurate diagnosis and treatments, reducing unnecessary referrals to specialists and the performance of more complex procedures.

Through the discourse analysis, the meanings effects produced by the words were analyzed from the discourses ${ }^{(9,17)}$. Comprehending the meanings related to the welcoming and bond pointed for NU1 and NU3, there are evidence that the $\mathrm{PHC}$ actions are fragile regarding the longitudinally aspect.

One of the functions of longitudinally analysis is the assumption of long-term responsibility about the user with continuity in relation to professional/team/unit of healthcare-user during lifetime, independently of the absence or the presence of the disease. Hence, to establish a bond during lifetime, it is necessary that there is a regular source of care and its use over time. A good welcoming is fundamental to consolidate bonding ${ }^{(2)}$.

We highlight the importance of the Primary Healthcare Networks (PHN) to diseases like TB, it is PHC Services' responsibility to articulate itself and to promote the bonds with the population ${ }^{(18)}$, as well as the socialization of the information and the knowledge coming from the TB's control policy for all of the care network providing care for the patient.

The FHS is considered strong in PHC scope to promote the creation of bonds between professionals and people with TB and their families, since the FHUs are responsible for the identification and treatment of the users, composing the gateway for accessing SUS ${ }^{(20)}$. The bond depends in the way that the teams take the responsibility for the healthcare of the people that lives in the coverage area. To be effective, it is necessary that the PHC professionals work on a consistent way knowing their importance and their role in PHC to build strong bonds with the community, making it trustful for the users.

However, the discourse from NU2 and $\mathrm{PH} 3$, we observed that the responsibility from the $\mathrm{PHC}$ professionals, which is necessary for developing bonds with TB patients, since these professionals encourage the sick people to look for the CHCF to be treated.

On the Levinasiana approach, the work must appear for the other, which is the product of reciprocity, which responds to their needs. Therefore, the work I do develop with the contact with the other, being responsible for the other ${ }^{(21)}$. It is evident that the PHC professionals, according to physicians and nurses from CHCF when they say "Go to Clementino" they don't take the responsibility for the user (the other) which is sick from TB. The aggravating factor of this action is that this user can take a long time to look for the $\mathrm{CHCF}$, which can delay the diagnosis and treatment, make his/her condition worse, and make him/her develop multiresistant TB.

The meanings effect are built on the interlocution process and this way they materialize inside of a relation of forces established by the interlocutors, which is affected by historical and social factors ${ }^{(17)}$. These PHC professionals are "running away from tuberculosis" and "sending them to Clementino", the TB patients of their units brings into their discursive memories some prejudice about the contact with the TB patient.

We highlight the concept of discursive memory or discursive meanings, understood as something that works before, in another place, regardless of the subject, and its mobilization 
occurs every time that the meaning is produced. So, the meaning of effect (re)produced are reverberate through the discursive memory: the discursive knowledge turns possible all the saying and returns as a pre-built form, the saying that already has been said, sustaining every word-taking ${ }^{(9)}$.

The concept of discursive memory is directly related to the concept of interdiscourse that is understood as the presence of different discourses, coming from different moments of history and from different social places ${ }^{(22)}$. In this sense, we can realize that the subject-position from the physician cited as $\mathrm{PH} 4$ was affected by the inter-discourse and was taken for the prejudice rooted to the disease.

We understand that the subject was interpellated by the interdiscourse because in the statements "Turn to the side that you are infecting, you have tuberculosis" and "put the mask because you are infected", this physician evokes a discursive memory or interdiscourse that advertises the identity from an age which TB was seen as a disease, avoiding direct contact with any person, contact could mean unwanted infection, not only by the physician point of view, but also by the moral point of view. As we known, the TB is an illness enclosed in taboos and beliefs of symbolic nature and surrounded by stigmas and prejudices ${ }^{(23)}$.

The prejudice against people with some diseases', which historically are stigmatizing, such as TB, generates many times more suffering and sequels than the disease itself. Negative impacts from prejudiced attitudes from some healthcare professionals against TB patients results in worsening self-esteem, poor adhesion and even the abandonment of the treatment, and many times the individual's family starts to act on a prejudiced way and reproduces discriminative attitudes that are observed from some healthcare professionals.

Due to prejudices, some daily obstacles arises both for the patient to assume and follow the treatment and for healthcare professionals on the actions and, ultimately, to control the disease $\mathrm{e}^{(23) .}$

Therefore, some possible interpretations could be circumscribed on the said "escaping" from TB patient by the PHC professionals. The first suggests that the prejudice is motivated by the fear of infection, and the second reinforces the role of the tertiary service for the treatment of the transmissible diseases. PHC professionals can attribute the sense or the comprehension that it is not good to follow TB treatment in the FHS, what opposes the guidelines of PNAB.

The position of the $\mathrm{PHC}$ professionals, according to their discourses on the ideological point of view, it indicates their cure conception of the disease and shows negatively the $\mathrm{PHC}^{\prime}$ role as the coordinator for the caring of the PHNs.

In what is related to integrality - which means the providing, for the healthcare team, a set of services that attends the population's needs attached to the promotion, prevention, cure, caring, rehabilitation and palliative care fields, the responsibilities to offer services in other places of healthcare attention, to the recognition of the biological, psychological and social problems that causes the diseases ${ }^{(12)}$ - it was realized as deficiency on the organization of the PHC services for TB control.

The early detection of the TB cases and an effective treatment are two powerful tools that provide the success on the disease control. The efforts of the healthcare services, noticeable in the
$\mathrm{PHC}$ ground must be concentrated in the ealy identification of sick patients and adequate treatment ${ }^{(24)}$.

A study conducted in the city of Rio de Janeiro showed the elevate search for assistance on the hospital emergence services by the TB patients, one explanation is due to frustrated attempts of the users to the diagnosis and treatment in PHC. The long time to obtain the diagnosis and the beginning of treatment would be related to the worsening of the clinical condition and the need for hospitalization ${ }^{(25)}$.

In this study, it is possible to realize from the discursive statements, the meanings, according to the CHCF professionals, the TB patients attribute to $\mathrm{PHC}$, one of them is the insecurity. In most cases, they look for $\mathrm{CHCF}$ not because of the worsening of their clinical condition, but because they feel insecure to look for PHC to be diagnosed and treated.

The organization of the healthcare services in Brazil presents a discontinuity of the attention, presenting a hospital-centred model and an absence of integration between the levels of assistance. Offering services in a continuous way, from the several levels of healthcare assistance, that is, integrated care for the users from SUS would reverse this fragmented model presented in

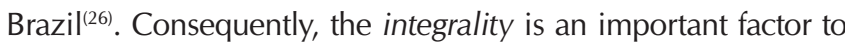
assure continuous assistance for the TB patient.

Regarding Coordination - which claims the capacity of assurance the continuity of care through healthcare team, with the recognition of the problems that requires the constant and articulated follow-up requiring the communication of the $\mathrm{PHC}^{(12)}$ - we can observe from the textual marks that were identified on the CHCF professionals' discourses some meanings that points to some dissatisfaction when it comes about an integrated work or the permanent articulation between the $\mathrm{PHC}$ and the $\mathrm{CHCF}$, such as the lack of integration between these services seen as critical points affecting the coordination.

Regarding PHNs, the PHC has a key role on its structure, the flows and the counterflows of caring is ordered and coordinated by it. Due to its relation with the users and their daily life, it should promote healthcare actions and link the points of attention as well as assure the integrality and continuity of care for the users ${ }^{(12)}$.

It is observed in the discursive statements that maybe, TB is not inserted in the specified PHN for the disease, considering the attribute coordination - which is a state of being in harmony on an common action or effort and that has its essence on the availability of information related to problems and previous services, and the recognition of that information, as far as it is related to the needs for the care ${ }^{(27)}$ - is not presented as an effective way in the local PHC for the following-up of the TB patients.

There is a problem, since the assistance coordination encourages an integrated work, permanent articulation of the healthcare services, assuring continuous assistance for the TB patient on treatment ${ }^{(27)}$. This common action or effort that is intrinsic to the coordination of the assistance doesn't hold the lack of responsibility for the other, the prejudice or the lack of communication between the services. In this context, the local PHC and the coordination of the assistance for the TB patient are fragile.

On the ideological point of view, the CHCF professionals, regarding their positions of professionals from the State 
Referral Services, interpret the attitudes as workers that seems to be working opposed to the TB control actions, because they are conditioned by the discursive memory. This fact contributes for negatively on welcoming and in the continuity of care for the TB patient, seeking help in the CHCF for the diagnosis and treatment of the disease, which opposites the policy of decentralization for the TB control's actions in the city.

It is important to clarify that in this study the guilt of the PHC fragility for the activities of TB control is not attributed only to its professionals. This problem must be also understood inside of a macro-political context, since those healthcare public policies were drawn with complex programs and services to PHC without offering the work conditions to the FHS, FHU and BHU, neither the technical, political and financial support correspondent to the municipal management.

The challenges for the PHC assumes the role as coordinator of the set of needs on healthcare users. Among the critical points mentioned by the literature, it stands out the lack of institutional policy directed to the strengthening of $\mathrm{PHC}$, the social representation of communities about the critical point of attention, the lack of social legitimacy, the restrict view of the managers that tend to comprehend it selectively. Moreover, there are a failure of qualifying resources for this strategy, which results on a noticeable deficiency of support and logistic devices that could favor the innovation of practices, the welcoming of the users and the bonding of them in $\mathrm{PHC}^{(28)}$.

Therefore, the integration and continuity of the TB patients care from the $\mathrm{PHC}$ professionals are compromised, emerging the need to debate about the possibility of rearrangement of the local healthcare system for the TB control, as well as an awareness of the $\mathrm{PHC}$ professionals when it comes about the decentralization of the TB control actions in PHC.

\section{Limitations of the study}

About the limitations of this study, we must mention: the participants were only professionals that work on the State reference service and, considering the qualitative approach, the results are not able to be generalized. Nevertheless, it is recommended additional researches involving professionals that work in PHC and the TB patients that look for primary care as the gateway for TB diagnosis and treatment, since it could bring different senses and meanings about the object of study unveiled here.

\section{Contributions for the healthcare area and public policy}

The contribution of this study for the field of knowledge of healthcare and public policy really matters, since that to approach this theme is something innovative and brings clarifications about the critical points on the actions of TB control linked to the PHC. In addition, the results found can bring awareness in some way for the PHC professionals to understand: the decentralization of the actions, planned to care for TB patient on a comprehensive and coordinated way, since it should already be occurring in practice; so, some changes are urgent to provide TB patients the services in the city of João Pessoa.

\section{FINAL CONSIDERATIONS}

The decentralization of the TB control actions for $\mathrm{PHC}$, in the City of João Pessoa, presents itself as a huge challenge for the city management. The professional's discourses from CHCF explicit the critical points affecting the essential attributes from PHC and its relation for TB control, as the difficult to access the diagnosis and treatment services, the lack of bond and actions of welcoming from the PHC professionals for the TB patient. These attitudes suggest prejudice and lack of communication between the services, and these are the identified points that compromises the early diagnosis and interpretation of the critical points, creating obstacles on the first contact to the long-term follow-up, integrality and coordination of the assistance for TB on local PHC.

It is necessary to make managers aware of the results that were found, suggesting the performance of other studies, with PHC professionals and TB patients, so that coping actions can be planned and executed with the objective to minimize the critical points that exists on PHC and to promote integrality of care to the TB patient, coordinated by the PHC services.

\section{REFERENCES}

1. Brasil. Ministério da Saúde. Secretaria de Atenção Básica. Departamento de Atenção Básica. Política Nacional de Atenção Básica. Séries Pactos pela Saúde. Brasília: (DF): Ministério da Saúde; 2006.

2. Giovanella L, Mendonça, MHM. Seletiva ou coordenadora dos cuidados? Rio de Janeiro: CEBES; 2012.

3. Brasil. Ministério da Saúde. Fundação Nacional de Saúde. Centro de Referência Prof. Hélio Fraga. Sociedade Brasileira de Pneumologia e Tisiologia. Controle de tuberculose: uma proposta de integração ensino-serviço. Rio de Janeiro; 2008.

4. Brasil. Ministério da Saúde. Secretaria de Vigilância em Saúde. Boletim Epidemiológico. Brasília: (DF): Ministério da Saúde; 2014.

5. Secretaria Municipal de Saúde de João Pessoa/SINAN/NET/SMS/JP. Dados de tuberculose do município de João Pessoa. Diretoria de Atenção à Saúde: João Pessoa, dezembro, 2015.

6. Secretaria Estadual de Saúde. Relatório estatístico e descritivo do núcleo hospitalar de epidemiologia do Complexo Hospitalar Clementino Fraga - 2011-2014. SES/PB/CHCF: João Pessoa, dezembro; 2015.

7. Oliveira RCC, Sa LD, Dias DCB, Pinheiro PGOD, Palha PF, Nogueira JA. Speeches of managers about the policy of the directly observed treatment for tuberculosis. Rev Bras Enferm [Internet]. 2015; [cited 2016 Jun 07] ;68(6):761-8. Available from: http:// www.scielo.br/pdf/reben/v68n6/en_0034-7167-reben-68-06-1069.pdf 
8. Chase RB, Aquilano NJ. Gestão da produção e das operações: perspectiva do ciclo de vida. Lisboa: Monitor, 1997.

9. Orlandi EP. Análise de discurso: princípios e procedimentos. 8ª . ed. São Paulo: Pontes; 2009.

10. Pêcheux M. Semântica e Discurso: uma crítica à afirmação do óbvio. Campinas: Unicamp; 1988.

11. Souza, SAF. Análise de discurso: procedimentos metodológicos. Manaus: Instituto Census, 2014.

12. Mendes EV. A construção social da atenção primária à saúde. Brasília: Conselho Nacional de Secretários de Saúde; CONASS; 2015.

13. Oliveira MAC, Pereira IC. [Primary Health Care essential attributes and the Family Health Strategy]. Rev Bras Enferm[Internet]. 2013[cited 2016 Jun 07];66(esp):158-64. Available from: http://www.scielo.br/pdf/reben/v66nspe/v66nspea20.pdf Portuguese

14. Escorel S, Giovanella L, Mendonça MHM, Magalhães R, Senna MCM. O Programa de Saúde da Família e a construção de um novo modelo para a atenção básica no Brasil. Rev Panam Salud Publica[Internet]. 2007[cited 2016 Jul 03];21(2-3):164-76. Available from: http://www.scielosp.org/pdf/rpsp/v21n2-3/11.pdf

15. Brasil. Ministério da Saúde. Secretaria de Vigilância em Saúde, Departamento de Vigilância Epidemiológica. Tratamento Diretamente Observado (TDO) da Tuberculose na Atenção Básica: protocolo de enfermagem. Brasília: (DF): Ministério da Saúde; 2011.

16. Santos TMMG, Nogueira LT, Arcêncio RA. Professional Practice of the Family Health Strategy in tuberculosis control. Acta Paul Enferm[Internet]. 2012 [cited 2016 Jun 02];25(6):954-961. Available from: http://www.scielo.br/pdf/ape/v25n6/en_v25n6a20.pdf

17. Pêcheux, M. O discurso: estrutura ou acontecimento. 3.ed Campinas: Pontes, 2002.

18. Mendes EV. As redes de atenção à saúde. Brasília: Organização Pan-Americana da Saúde; 2011.

19. Oliveira RCC, Adário KDO, Sá LD, Videres ARN, Souza SAF, Pinheiro PGOD. Manager's discourse about information and knowledge related to the tuberculosis directly observed treatment. Texto Contexto Enferm[Internet]. $2016[$ cited 2016 Jul 07];25(2):e3210015. Available from: http://www.scielo.br/pdf/tce/v25n2/0104-0707-tce-25-02-3210015.pdf

20. Gomes, ALG; Sá, LD. As concepções de vínculo e a relação com o controle da tuberculose. Rev Esc Enferm USP[Internet]. 2009[cited 2016 Jul 07];43(2): Available from: http://www.scielo.br/pdf/reeusp/v43n2/a16v43n2.pdf

21. Lévinas E. Entre nós: ensaios sobre a alteridade. 5.ed. Petrópolis: Vozes, 2010.

22. Fernandes CA. Análise do discurso: reflexões introdutórias. $2^{\text {a }}$ ed. São Carlos: Claraluz; 2008.

23. Andrade SLE, Pinheiro PGOD, Oliveira RCC, Alcântara LM, Villa TCS, Nogueira JA, Sá LD. The adherence for the tuberculosis treatment: the mark of stigma in the discourse of nurses. Int Arch Med [Internet]. 2016 [cited 2016 Jun 23];9(94). Available from: http://imed.pub/ojs/index.php/iam/article/view/1585

24. Pinheiro PGOD, Sá LD, Palha PF, Souza FBA, Nogueira JA, Villa TCS. [Active search for respiratory symptoms and late diagnosis of tuberculosis]. Rev Rene [Internet]. 2012[cited 2016 May 30]13(3):572-81. Available from: http://www.revistarene.ufc.br/revista/ index.php/revista/article/view/724/pdf Portuguese

25. Costa PV, Senna AL, Oliveira LGD, Siqueira RCAG, Figueiredo SP. Demora no diagnóstico da tuberculose pulmonar em cinco municípios da região metropolitana do Rio de Janeiro, Brasil, 2009-2010. Cad Saúde Colet[Internet]. 2012[cited 2016 May 30];20(2):195-202. Available from:http://www.cadernos.iesc.ufrj.br/cadernos/images/csc/2012_2/artigos/csc_v20n2_195-202.pdf

26. Mendes EV. O dilema fragmentação ou integração dos sistemas de serviços de saúde: por sistemas integrados de serviços de saúde. In: Mendes EV. Os grandes dilemas do SUS. Tomo 2. Casa da Qualidade Editora: Salvador; 2001.

27. Starfield B. Atenção Primária: equilíbrio entre necessidades de saúde, serviços e tecnologia. Brasília: Organização das Nações Unidas para a Educação, a Ciência e a Cultura/Ministério da Saúde; 2002.

28. Rodrigues LBB, Leite AC, Yamamura M, Deon KC, Arcêncio RA. Coordenação das redes de atenção à saúde pela atenção primária: validação semântica de um instrumento adaptado. Cad Saúde Pública[Internet]. 2014[cited 2016 Jun 23];30(7):1385-90. Available from:http://www.scielo.br/pdf/csp/v30n7/0102-311X-csp-30-7-1385.pdf 